\title{
Population dynamics and diversity of phytoplankton, bacteria and viruses in a seawater enclosure
}

\author{
A. Larsen ${ }^{1, *}$, T. Castberg ${ }^{1}$, R. A. Sandaa ${ }^{1}$, C. P. D. Brussaard ${ }^{2}$, J. Egge $^{3}$, M. Heldal ${ }^{1}$, \\ A. Paulino ${ }^{3}$, R. Thyrhaug ${ }^{1}$, E. J. van Hannen ${ }^{4}$, G. Bratbak ${ }^{1}$ \\ ${ }^{1}$ Department of Microbiology, University of Bergen, Jahnebakken 5, 5020 Bergen, Norway \\ ${ }^{2}$ Department of Biological Oceanography, Netherlands Institute for Sea Research, PO Box 59, 1790 AB Den Burg, Texel, \\ The Netherlands
}

${ }^{3}$ Department of Fisheries and Marine Biology, University of Bergen, Bergen High Technology Centre, 5020 Bergen, Norway

${ }^{4}$ Department of Microbial Ecology, Centre for Limnology, Netherlands Institute of Ecology, PO Box 1299, 3600 BG Maarssen, The Netherlands

\begin{abstract}
We now know that the abundance of free viruses in most marine environments is high. There is still, however, a lack of understanding of their occurrence and distribution and of in situ relationships between viral and host communities in natural environments. This may be partly due to methodological limitations. Our main aim was therefore to perform a case study in which a variety of methods were applied in order to give an improved, high-resolution description of the microbial communities in a natural environment. In order to do this we combined light microscopy (LM), transmission electron microscopy (TEM), flow cytometry (FCM), PCR denaturing gradient gel electrophoresis (PCR-DGGE) and pulsed-field gel electrophoresis (PFGE) and studied the diversity and succession of algae, bacteria and viruses in a nutrient enriched seawater enclosure. In the enclosure we experienced a situation where the development of the dominating algal population, which consisted of several flagellate species, was followed by proliferation of several different size-classes of viruses. The total bacterial number decreased markedly during the flagellate bloom but the community composition was maintained and the diversity remained high. Our results indicate a close linkage between various algal, bacterial and viral populations and show that virioplankton do not necessarily terminate algal and bacterial blooms but that they keep the host populations at non-blooming levels.
\end{abstract}

KEY WORDS: Bacteria $\cdot$ DGGE $\cdot$ Diversity $\cdot$ Flow cytometry $\cdot$ Light microscopy $\cdot$ PFGE $\cdot$ Phytoplankton · Virus

Resale or republication not permitted without written consent of the publisher

\section{INTRODUCTION}

During the last $10 \mathrm{yr}$ it has become clear that viruses are extremely abundant in the marine environment and that they infect a variety of important primary producers (Bergh et al. 1989, Cotrell \& Suttle 1991, Bratbak et al. 1993, Suttle \& Chan 1995, Nagasaki et al. 1995, Jacobsen et al. 1996). Until now, lack of appropriate methods for studying occurrence and diversity

*E-mail: aud.larsen@im.uib.no of algal and bacterial viruses in large numbers of samples has limited our knowledge of in situ relationships between viral and host communities in natural environments (Proctor 1997, Wommack \& Colwell 2000). We therefore conducted an experiment in which we created a bloom situation in a mesocosm and combined several methods for detecting, identifying and enumerating algae, bacteria and viruses during the bloom.

Flow cytometry (FCM) is commonly accepted as a reference technique in the field of marine planktonology. The technique, which measures light scattering 
and fluorescence characteristics from individual particles, has long been recognised as a reliable tool for rapid and accurate counting of algae and bacteria in aquatic samples (see reviews by Troussellier et al. 1993, Collier 2000 and Vives-Rego 2000). Recently Marie et al. (1999a) also reported the successful use of a standard flow cytometer to detect and enumerate viruses in seawater. In the current study we employed FCM to monitor the development and numbers of dominating algal, viral and bacterial populations.

Denaturing gradient gel electrophoresis (DGGE) of rDNA fragments is now widely used for assessing the development in mixed microbial communities. One of the advantages of the method is the simultaneous analysis of multiple samples, which allows monitoring of complex microbial dynamics (Muyzer et al. 1993). Several workers have shown the usefulness of the method for studying changes in bacterial communities (Muyzer 1999 and references therein). Recently van Hannen et al. (1999) also applied the technique to examine eukaryal microbial organisms after viral lysis. DGGE does not yield quantitative information, but the number of bands visualises the species richness in a sample, and strong bands may be used as an indication of the presence of a dominant organism (Schauer et al. 2000). Sequencing DNA from cut-out DGGE bands can be applied to compare bands at the same position at different time points in order to decide whether the same organism persists in the samples or if another with the same migration pattern appears. The sequence data may also give an indication of species identity. We used PCR-DGGE in combination with light microscopy (LM) and FCM in order to describe the eukaryote algal and the bacterial composition with as much detail as possible.

Few methods are available for ecological studies of viral diversity in water systems, and using pulsed-field gel electrophoresis (PFGE) for diversity studies of viruses is a relatively new approach (Wommack et al. 1999). The method, which relies on a direct current electric field that periodically changes direction and/or intensity relative to an agarose gel, allows improved resolution by length up to $12 \mathrm{Mb}$ (Maule 1998). One of the main benefits of PFGE is that there is no need for any knowledge of common traits of the viral population prior to preparation. Furthermore, no amplification steps such as PCR, are necessary prior to analysis, limiting the possibility for bias. PFGE offers a great improvement in the ability to detect and quantify changes in the viral population. In the current study we therefore applied this method for monitoring viral diversity and succession in detail.

The aim of this study was to give a detailed picture of changes occurring in planktonic algal, bacterial and viral populations. For this purpose we chose to use a nutrient seawater enclosure, which bridges the gap between the laboratory and the aquatic environment (Egge 1993), and performed a case study in which the above-described methods were applied in combination with microscopy.

\section{MATERIALS AND METHODS}

Experimental design, abiotic parameters, primary production and chl $\mathbf{a}$. The mesocosm experiment was carried out at the Marine Biological Field Station, Espeland, $20 \mathrm{~km}$ south of Bergen, western Norway from 16 April to 6 May 1999. The enclosure was mounted on floating frames that were moored to a raft in the middle of the bay (for details see Egge \& Aksnes 1992). It was $4 \mathrm{~m}$ deep and $2 \mathrm{~m}$ wide $\left(\mathrm{vol}=11 \mathrm{~m}^{3}\right)$ and made of $0.15 \mathrm{~mm}$ thick polyethylene $(90 \%$ light penetration, PAR). The enclosure was filled with post-bloom seawater from $2 \mathrm{~m}$ depth, and the water was kept homogenous by means of an airlift.

The enclosure was enriched with nitrate $\left(\mathrm{NaNO}_{3}\right)$ and phosphate $\left(\mathrm{K}_{2} \mathrm{HPO}_{4}\right)$. The first nutrient addition, given on Day 4, raised the concentration of nitrate to $8 \mu \mathrm{M}$ and the concentration of phosphate to $0.5 \mu \mathrm{M}$. In order to avoid nitrate or phosphate limitation we provided the enclosure with smaller amounts of nutrients $\left(4 \mu \mathrm{M} \mathrm{NaNO}_{3}\right.$ and $0.25 \mu \mathrm{M} \mathrm{K}_{2} \mathrm{HPO}_{4}$ ) on Day 7 and Day 13.

Nitrate, phosphate and silicate concentrations were determined in a Skalar autoanalyzer on samples preserved with $1 \%$ (v/v) chloroform (Hagebø \& Rey 1984). The samples were centrifuged prior to preservation at $10000 \times g(\max )$ for $15 \mathrm{~min}$ in order to remove most particulate matter. Samples were stored at $10^{\circ} \mathrm{C}$ until analysis.

Primary production was measured by the ${ }^{14} \mathrm{C}$ method (Steeman Nielsen 1952, Gargas 1975) with modifications as described in Egge \& Jacobsen (1997). Samples for chl a were analysed fluorometrically in a Turner Designs Fluorometer Model 10-AU, after filtration on Sartorius membrane filters $(0.45 \mu \mathrm{m})$ and extraction in $90 \%$ acetone (Parsons et al. 1984). The sampling interval was 1 to $2 \mathrm{~d}$. Seawater temperature and salinity (PSU) were measured with an OTS, Isi Model 85, once a week.

Light microscopy (LM). Counting and identification of phytoplankton was carried out on samples preserved in Lugol glutaraldehyde (final concentration of $1 \%$ ) using the sedimentation method of Utermöhl (1931). Whenever possible, the phytoplankters were identified to species.

Transmission electron microscopy (TEM). Some samples from the enclosure were inspected by TEM. The samples were fixed with $2.5 \%$ glutaraldehyde and 
harvested by ultracentrifugation onto electron microscope grids as described in Bratbak \& Heldal (1993). The grids were stained with $2 \%$ uranyl acetate and viewed at 30000 to $50000 \times$ magnification in a JEOL 100S transmission electron microscope.

Flow cytometry (FCM). All FCM analyses were performed with a FACSCalibur flow cytometer (Becton Dickinson, Franklin Lakes, NJ) equipped with an aircooled laser providing $15 \mathrm{~mW}$ at $488 \mathrm{~nm}$ and with standard filter set-up. For algal counts, fresh samples were analysed. The trigger was set on red fluorescence and samples were analysed for 90 to $300 \mathrm{~s}$ at an average flow rate of $71.5 \mu \mathrm{l} \mathrm{min}{ }^{-1}$. Enumeration of viruses and bacteria was performed on samples fixed with glutaraldehyde for $30 \mathrm{~min}$ at $4^{\circ} \mathrm{C}$, quickly frozen in liquid nitrogen and stored at $-70^{\circ} \mathrm{C}$ until further analysis. The final glutaraldehyde concentration was $0.5 \%$ in virus samples and $0.1 \%$ in bacterial samples (Marie et al. 1999b).

The samples were thawed immediately before staining and analysis. The thawed virus samples were diluted 10- to 100-fold in TE buffer (Tris 10 mM, EDTA $1 \mathrm{mM}, \mathrm{pH} 8$ ) and stained with SYBR Green I (Molecular Probes Inc., Eugene, OR) for $10 \mathrm{~min}$ at $80^{\circ} \mathrm{C}$ in the dark (Marie et al. 1999a). The thawed bacterial samples were diluted 5- to 10-fold in TE buffer and stained with SYBR Green I for $15 \mathrm{~min}$ at room temperature in the dark. The final dilution of SYBR Green I was usually $1.0 \times 10^{-4}$ of the commercial stock solution (Marie et al. 1999a). However, when the viral concentration was low we sometimes used $0.5 \times 10^{-4}$ as this concentration then gave less signal noise in the viral samples. Fluorescent microspheres (Molecular Probes Inc.) with a diameter of $0.95 \mu \mathrm{m}$ were added to all samples as an internal standard. The discriminator was set on green fluorescence and the samples were analysed for $1 \mathrm{~min}$ at a viral event rate between 100 and $1000 \mathrm{~s}^{-1}$. For a more detailed description of flow cytometer instrumentation see Marie et al. (1999b).

Pulsed-field gel electrophoresis (PFGE). For the PFGE analyses 21 of sample was concentrated using the Vivaflow 200 (Vivascience, Lincoln, UK) tangial flow module, with a cut-off on 100000 , following the manufacturer's procedure. The concentrate was clarified by centrifuging in a swing-out centrifuge (Beckmann J2-HS) at $7500 \mathrm{rpm}$ for $30 \mathrm{~min}$ at $4^{\circ} \mathrm{C}$. The supernatant was then decanted and the procedure repeated once. The viral particles were subsequently concentrated by an ultracentrifuge (Beckman L8-M with SW28 rotor) for $2 \mathrm{~h}$ at $28000 \mathrm{rpm}$ at $10^{\circ} \mathrm{C}$. The viral pellet was resuspended and incubated overnight in $400 \mu \mathrm{l}$ $\mathrm{SM}$ buffer $\left(0.1 \mathrm{M} \mathrm{NaCl}, 8 \mathrm{mM} \mathrm{MgSO}_{4} 7 \mathrm{H}_{2} \mathrm{O}, 50 \mathrm{mM}\right.$ Tris- $\mathrm{HCl}_{1} 0.005 \%$ (w/v) glycerine; Wommack et al. 1999) at $4{ }^{\circ} \mathrm{C}$. Equal volumes of viral concentrate and molten $1.5 \%$ InCert agarose (FMC, Rockland, Maine) were mixed and dispensed into plug moulds. After the gel had solidified the plugs were punched out from the moulds into a small volume of buffer (250 mM EDTA, $1 \% \mathrm{SDS}$ ) containing $1 \mathrm{mg} \mathrm{ml}^{-1}$ Proteinase $\mathrm{K}$. The plugs were incubated in the dark at $30^{\circ} \mathrm{C}$ overnight. The Proteinase $\mathrm{K}$ digestion buffer was decanted and the plugs were washed 3 times, for $30 \mathrm{~min}$ each, in TE buffer (10 mM Tris-Base, $1 \mathrm{mM}$ EDTA, pH 8.0). The virioplankton agarose plugs were stored at $4^{\circ} \mathrm{C}$ in TE 20:50 (20 mM Tris, 50 mM EDTA, pH 8.0).

Plugs containing phage lambda concatamers (BioRad, Richmond, CA) served as molecular weight markers. These and the viral plugs were placed into wells of a $1 \%$ SeaKem GTG agarose (FMC, Rockland, Maine) gel in $1 \times$ TBE gel buffer (90 mM Tris-borate, and $1 \mathrm{mM}$ EDTA, pH 8.0) with an overlay of molten $1 \%$ agarose. Samples were run using a Bio-Rad DR-II CHEF Cell (Bio-Rad) electrophoresis unit operating at $6 \mathrm{~V} \mathrm{~cm}^{-1}$ with pulse ramps from 20 to $45 \mathrm{~s}$ at $14^{\circ} \mathrm{C}$ for $23 \mathrm{~h}$ in $0.5 \times$ TBE tank buffer $(45 \mathrm{mM}$ Tris-borate, and $1 \mathrm{mM}$ EDTA, pH 8.0). After electrophoresis, the gels were stained for $30 \mathrm{~min}$ in SYBR green I (Molecular Probes Inc.) according to manufacturer's instructions and digitally scanned for fluorescence using a laser fluoroimager (Fuji Film, FLA 2000). We applied densiometer software in order to quantify the signal intensities of each band. By comparing the signals with the signal of a standard with known size and known amount of DNA, the relative abundance of each of the viruses with different genome size was calculated.

PCR-DGGE. For bacterial preparations, $10 \mathrm{ml}$ sea water samples were filtered on $0.2 \mu \mathrm{m}$ DynaGard hollow fibre syringe filters (Microgon Inc., Laguna Hills, CA) and stored at $-70^{\circ} \mathrm{C}$ until further processing. For DNA isolation Wizard ${ }^{\circledR}$ Genomic DNA Purification Kit (Promega cat. no A1120) was used. $200 \mu$ l Nuclei Lysis Solution was added to the filters, and lysis was enhanced by 3 freeze/thaw cycles of $2 \mathrm{~min}$ at $-40^{\circ} \mathrm{C}$ and $95^{\circ} \mathrm{C}$. The lysates were centrifuged out of the filters $(6000 \times g$ for $2 \mathrm{~min})$ after inverting them in an Eppendorf tube. Additional $200 \mu$ l Nuclei Lysis Solution was added to the filters and recollected in Eppendorf tubes by centrifugation. $150 \mu$ l Protein Precipitation Solution was added to $400 \mu$ lysate. The sample was then vortexed, chilled on ice for $5 \mathrm{~min}$ and centrifuged at $1300 \times g$ for $2 \mathrm{~min}$. The DNA was precipitated from the supernatant with isopropanol, centrifuged and washed once with $70 \%$ ethanol. The DNA pellet was dried and resuspended in $30 \mu \mathrm{l} 1 \times \mathrm{TE}$ buffer.

The V3 region of the bacterial 16S rRNA gene was amplified using the primer set 338f (5' ACTCCTACGGGAGGCAGCAG, Øvreås et al. 1997) with a 40 mer GC clamp in the 5' end (5' CGCCCGCCGCGCGCGGCGGGCGGGGCGGGGGCACGGGGGG), and 
PRU517r (5' ATTACCGCGGCTGCTGG; Muyzer et al. 1993). A $100 \mu l$ reaction-mixture contained sterile distilled water, PCR-buffer (standard $10 \times$ PCR buffer, Perkin-Elmer), dNTPs (each $200 \mathrm{nM}$ ), primers (pru517, $1 \mathrm{M}$; 338GC, $0.26 \mathrm{M}), 2.5 \mathrm{U}$ AmpliTaq Gold DNA polymerase (Perkin-Elmer) and 2 to 4 ng template amplicon. An initial denaturation step at $96^{\circ} \mathrm{C}$ for 9 min to activate the AmpliTaq GOLD was followed by 35 of the following cycles: $95^{\circ} \mathrm{C}$ for $30 \mathrm{~s}, 54^{\circ} \mathrm{C}$ for $1 \mathrm{~min}$ and $30 \mathrm{~s}$, $72^{\circ} \mathrm{C}$ for $30 \mathrm{~s}$. The cycles were followed by an extension step of $72^{\circ} \mathrm{C}$ for $6 \mathrm{~min}$. The amplification products were checked for length and purity on a $1.5 \%$ agarose gel before they were concentrated by evaporation to $50 \%$ of the initial volume.

DGGE for the bacteria was performed using a Hoeffer SE600 gel electrophoresis unit. Polyacrylamide gels $(8 \%(\mathrm{w} / \mathrm{v})$ bisacrylamide gel stock solution 37:5:1 (Bio Rad Laboratories Inc.) in $0.5 \times$ TAE buffer) were made with a gradient of 20 to $45 \%$ denaturant in $0.5 \times \mathrm{TAE}$ buffer. The denaturant solution $(100 \%)$ was made of 7.0 M Urea and $40 \%(\mathrm{v} / \mathrm{v})$ formamide. $1 \times$ TAE buffer was made of $4.0 \mathrm{mM}$ Tris-base, $2.0 \mathrm{mM}$ sodium acetate and $1.0 \mathrm{mM}$ EDTA; pH-adjusted to 7.4. A sample $(20 \mu \mathrm{l})$ of the concentrated PCR products was used for the DGGE, performed in $0.5 \times \mathrm{TAE}$ buffer at $60^{\circ} \mathrm{C}$, first at $20 \mathrm{~V}$ for $10 \mathrm{~min}$ and then at $200 \mathrm{~V}$ for $2.5 \mathrm{~h}$. The gels were stained for $1 \mathrm{~h}$ with a 1:10000 dilution of SYBR Green II (Molecular Probes Inc.) in $0.5 \times$ TAE buffer before photographing.

DNA preparations for the eukaryotic primers were made as for the bacterial samples, with some modifications. The $50 \mathrm{ml}$ seawater sample was filtered on $1.0 \mu \mathrm{m}$ polycarbonate membrane filters. The filters were soaked in $600 \mu \mathrm{l}$ lysis solution and they were shaken for $30 \mathrm{~min}$ prior to the freeze/thaw cycles. Protein Precipitation Solution $(200 \mu \mathrm{l})$ was used and the DNA was resuspended in $50 \mu \mathrm{l} 1 \times \mathrm{TE}$ buffer.

We performed the PCR-DGGE for the eukaryotes using the protocol exactly as described by van Hannen et al. (1998). Some bands from the gels were cut out and the product was sequenced by cycle sequencing, using the reverse R1616 primer.

\section{RESULTS}

\section{Abiotic variables, chl $a$, and primary production}

Before the initial nutrient addition on Day 4, nitrate and phosphate concentrations were ca $1 \mu \mathrm{M}$ and $0.2 \mu \mathrm{M}$ respectively. After the initial nutrient addition, the phosphate concentration was always $>0.2 \mu \mathrm{M}$ and thus probably never limiting. The nitrate concentration was normally well above $1.1 \mu \mathrm{M}$ and always $>0.8 \mu \mathrm{M}$, except on Day 20 when it dropped to $0.4 \mu \mathrm{M}$. Silicate concentrations had initial values around $2 \mu \mathrm{M}$ and decreased to $<0.5 \mu \mathrm{M}$ towards the end. The temperature increased from an average of 5.8 to $8.8^{\circ} \mathrm{C}$, and the salinity from 28.9 to 31.2 PSU during the experimental period (nutrient, temperature and salinity data are not shown in the figs below).

The initial chl a concentration was about $2 \mu \mathrm{g} \mathrm{l^{-1 }}$ (Fig. 1). The concentration was low until Day 9, then increased rapidly and peaked on Day 13 . The chl a maximum coincided with the major primary production maximum while no such coincidence could be found with the smaller maximum in primary production that appeared at Day 17 (Fig. 1).

\section{FCM}

Flow cytometric counts of characteristic algae, bacteria and viruses are shown in Fig. 2. Two major groups of algae were observed. One, labelled A2, with relatively low red autofluorescence (RFL) and sidescatter (SSC) values (Fig. 3a) culminated on Day $7(2.5 \times$ $10^{4}$ cells $\mathrm{ml}^{-1}$, Fig. 2a). Another group, labelled A1, with higher RFL and SSC values (Fig. 3a), reached a maximum on Day 14 with $3.7 \times 10^{4}$ cells ml $^{-1}$ (Fig. 2a). Two minor algal groups, A3 and A4, were most abundant at the beginning of the experiment, with cell numbers around $3 \times 10^{3} \mathrm{cells} \mathrm{ml}^{-1}$ and $2 \times 10^{3} \mathrm{cells} \mathrm{ml}^{-1}$ respectively. A3 had low SSC and RFL values, but high orange autofluorescence (OFL, not shown), while A4 had high OFL (not shown), RFL and SSC values.

We found 2 distinct groups of viruses (Fig. 3b). The one labelled V1 had substantially higher SSC values and slightly higher green fluorescence (GFL) values than the group labelled V2. The V2 viruses showed a small maximum around Days 7 to 9, which coincided with the decrease in the algal group A2 (Fig. 2a,b). The abundance of V2 decreased throughout the experi-

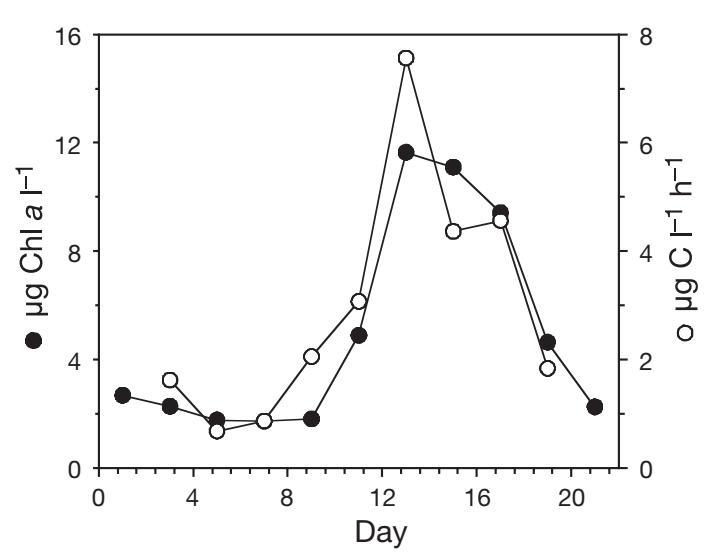

Fig. 1. Biomass (chl a) and primary production in the mesocosm 


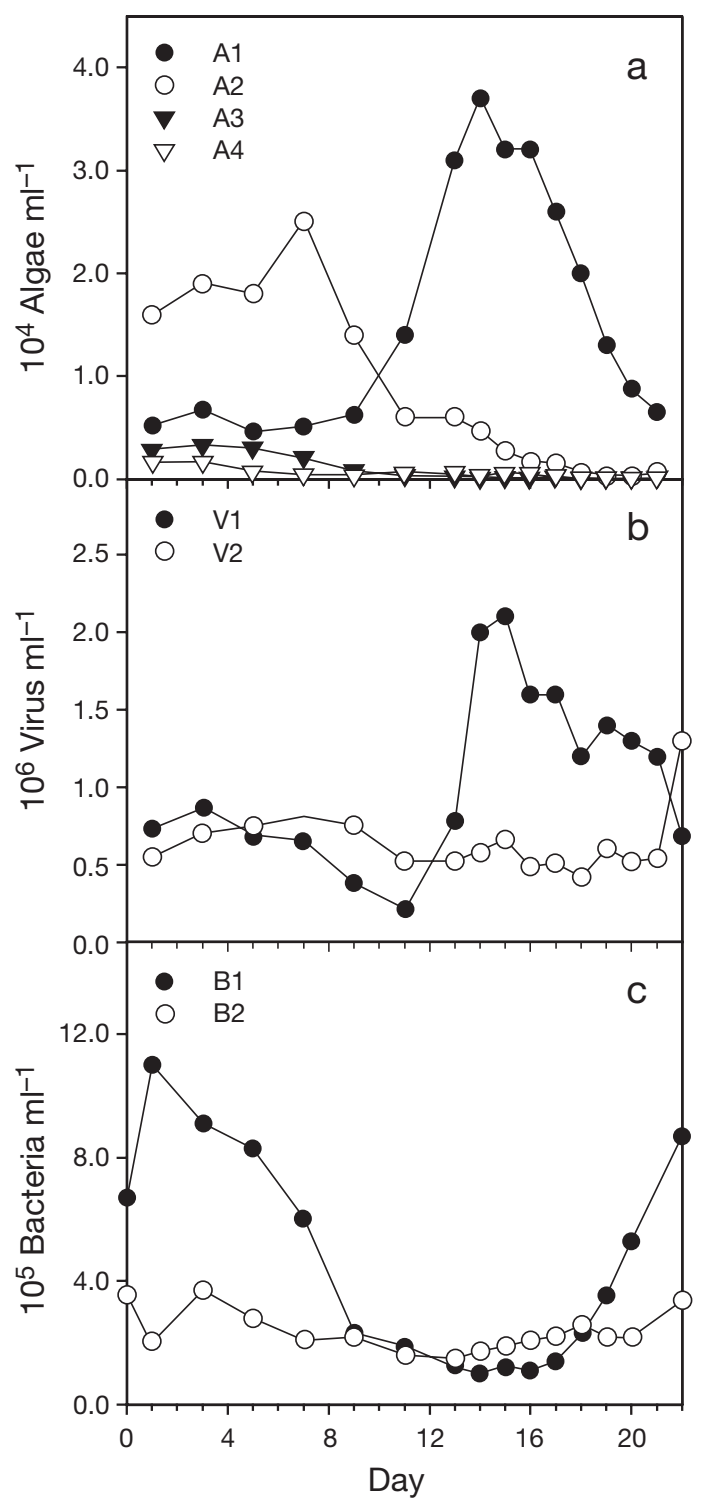

Fig. 2. Development of algae, viruses and bacteria as determined by flow cytometry. (a) Abundance of dominating algal groups: (A1) mixed flagellates, (A2) Micromonas-like algae, (A3) Synechococcus-like algae, (A4) Cryptophyte-like algae. (b) Numbers of (V1) large viruses and (V2) small viruses. (c) Numbers of bacteria with (B1) high, and (B2) low DNA content

ment, but with a significant increase on the last day (Day 22). The V1 viruses decreased during the first $11 \mathrm{~d}$ of the experiment after which they increased rapidly to $2 \times 10^{6}$ on Day 14 (Fig. $2 b$ ). The increase in V1 followed the increase in A1, and as A1 collapsed, V1 decreased in abundance (Fig. 2a,b).

The bacteria present were separated into 2 groups, one with a higher GFL signal (B1) than the other (B2), indicating a higher DNA content (Fig. 3b). The abun- dance of B1 decreased during the first half of the experiment and increased again towards the end (Fig. 2c). B2 fluctuated around $0.4 \times 10^{6} \mathrm{cells} \mathrm{ml}^{-1}$ throughout the whole experiment (Fig. 2c).

\section{LM}

The algal community included a mixture of several species of diatoms, dinoflagellates and other flagel-
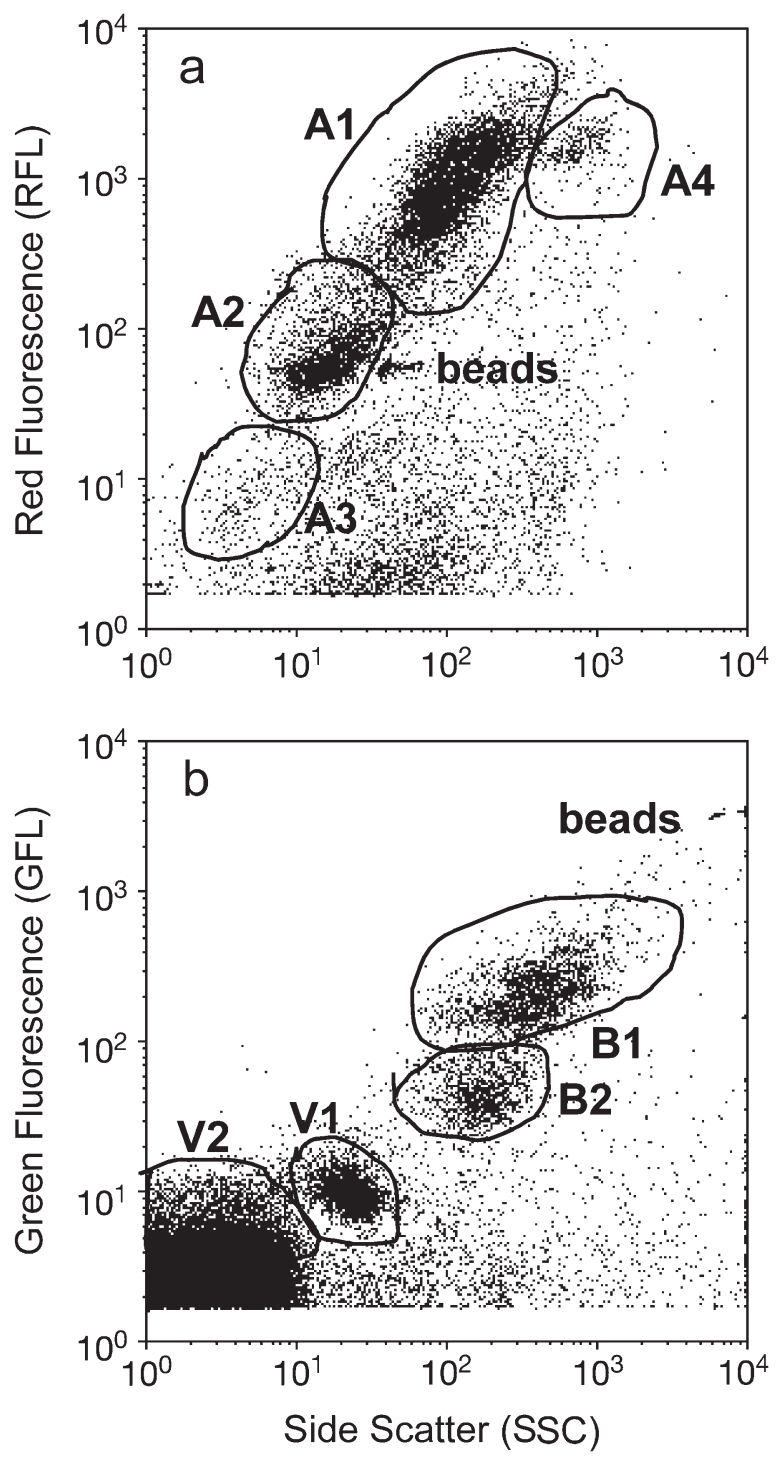

Fig. 3. Biparametric flow cytometry plots showing characteristic populations of algae, viruses and bacteria. (a) Side scatter versus red fluorescence, showing the following algal subpopulations: (A1) mixed flagellates, (A2) Micromonas-like algae, (A3) Synechococcus-like algae, (A4) Cryptophyte-like algae. (b) Side scatter versus green fluorescence showing bacterial sub-populations with high (B1) and low (B2) DNA content, and both large (V1) and small (V2) viral sub-populations 
lates. Seven diatom species or genera (Chaetoceros sp., Cylindrotheca closterium, Licmophora spp., Navicula spp., Nitzschia longissima, Skeletonema costatum, Thalassiosira nitzschioides) were identified and the maximum diatom abundance (a total of $3.0 \times 10^{3}$ cells $\mathrm{ml}^{-1}$ ) was found on Day 15. Thirteen dinoflagellate species or genera (Ceratium furca, C. horridum, C. longipes, C. tripos, Gymnodinium galatheanum, Gyrodinium spirale, Gyrodinium sp., Heterocapsa rotundata, Noctiluca scintillans, Protoperidinium brevipes, P. pellucidum, Protoperidinium sp., Scripsiella sp.) were identified and $H$. rotundata made up the majority of these $\left(2.8 \times 10^{3} \mathrm{ml}^{-1}\right.$ on Day 15$)$. However, other flagellates dominated the algal community and 3 main peaks were observed (Fig. 4). Unidentified flagellates sized from 2 to $5 \mu \mathrm{m}$ peaked on Day $13\left(9 \times 10^{4}\right.$ cells $\mathrm{ml}^{-1}$ ) and most of these were algae with Prymnesiophyceae-like chloroplasts. Prasinophytes (mainly Pyramimonas sp., $3 \times 10^{4}$ cells $\mathrm{ml}^{-1}$ ) and 6 to $10 \mu \mathrm{m}$ sized unidentified flagellates reached maximum abundance on Day $15\left(9 \times 10^{3}\right.$ cells $\left.\mathrm{ml}^{-1}\right)$. Some samples from the enclosure were inspected by TEM. Detached organic scales specific for $H$. rotundata, Pyramimomas cirolanae and Pyramimomas sp. were found to dominate together with scales originating from Chrysochromulina polylepis and another Chrysochromulina species not yet described (results not shown). This suggests that some of the unidentified flagellates from both size groups are probably species of Chrysochromulina.

\section{PFGE}

At least 20 different viral populations could be distinguished by pulsed field gel electrophoresis (Fig. 5). The genome size of the viruses ranged from 17 to $485 \mathrm{kbp}$ and the relative abundance of the different populations showed a general decrease with increasing genome size (Fig. 5a). The viruses with small genome sizes (17 to $65 \mathrm{kbp}$ ) were most abundant and made up 81 to $99 \%$ of the community during the experimental period. Medium genome-sized viruses (87 to $230 \mathrm{kbp}$ ) and large genome-sized viruses (269 to $485 \mathrm{kbp}$ ) made up 1 to $16 \%$ and 0 to $3 \%$ respectively.

The abundance of the different populations changed significantly between successive sampling dates. Viruses with genome size $224 \mathrm{kbp}$ and $230 \mathrm{kbp}$ showed a maximum abundance on Day 7 (Fig. 5b) coinciding with the V2 with peak on Days 7 to 9 , and a decrease in the algal population A1 (Fig. 2). Viruses with genome size 87, 109, 189 and $194 \mathrm{kbp}$ all had maximum abundance on Day 13 (Fig. 5b) and in turn coinciding with a peak in V1 on

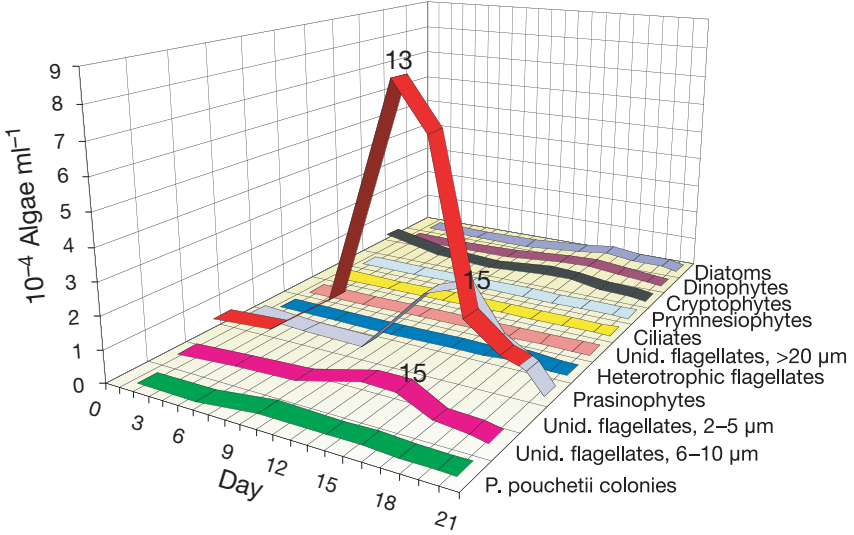

Fig. 4. Abundance of algae and ciliates as determined by light microscope. 'Prymnesiophytes' contain prymnesiophytes other than Phaeocystis pouchetii colonies
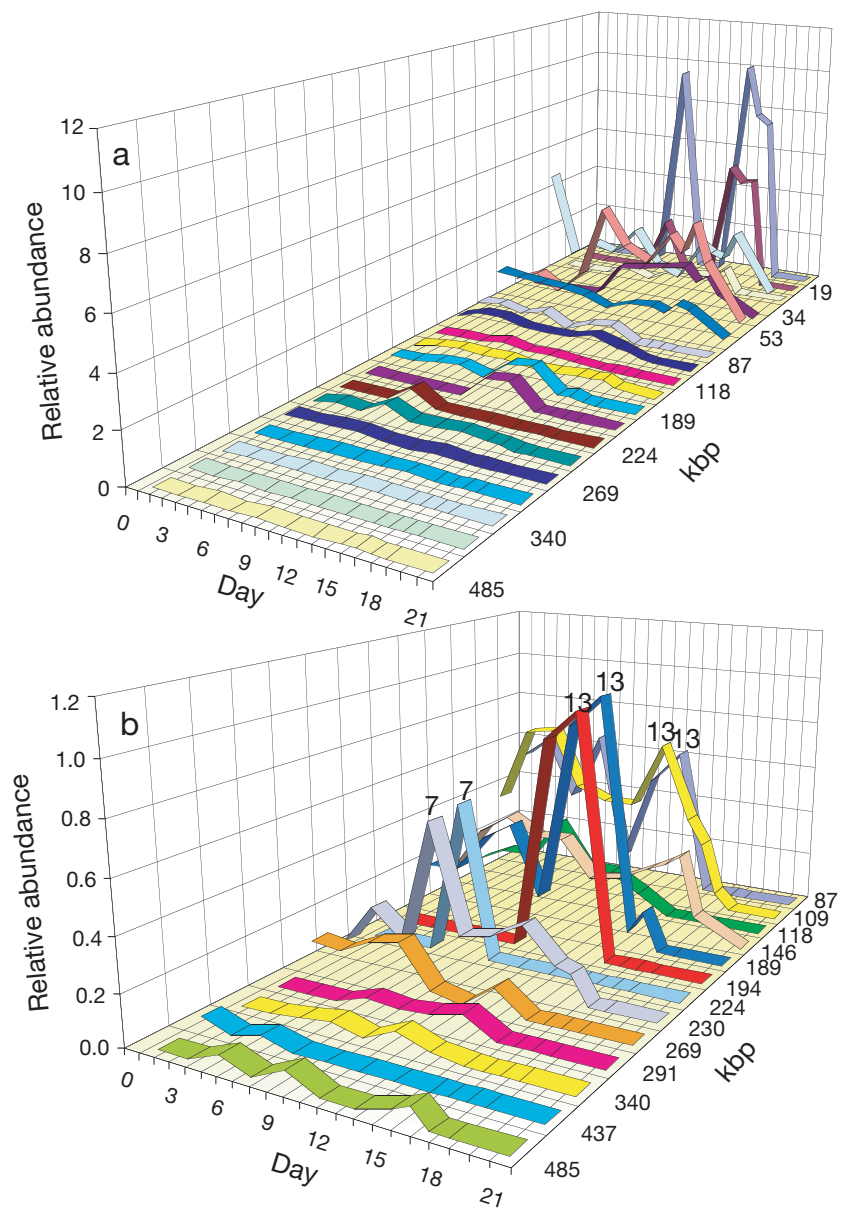

Fig. 5. Relative abundance of distinct viral populations determined by PFGE. Populations defined by genome size. (a) Viruses of all size classes; (b) viruses larger than $87 \mathrm{kbp}$. Day of maximum abundance is indicated for the 6 most prominent viruses larger than $87 \mathrm{kbp}$ 
Day 14/15 and a concomitant decline in the algal population A2 (Fig. 2).

\section{PCR-DGGE}

With DGGE analysis of the eukaryotic rDNA we found 8 to 14 distinguishable bands on each sampling day and throughout the entire experimental period a total of 36 different band positions (Fig. 6a). Four populations dominated over a period of more than $5 \mathrm{~d}$. The band at position 0.7 was present from Days 0 to 15 . The band at position 4.4 appeared strong from Days 4 to 16 and then decreased significantly in intensity. The band at position 5.1 appeared strong from Days 0 to 12 before it disappeared on Days 13 and 14 and reappeared on Days 15 and 16. Sequence data show that the bands at position
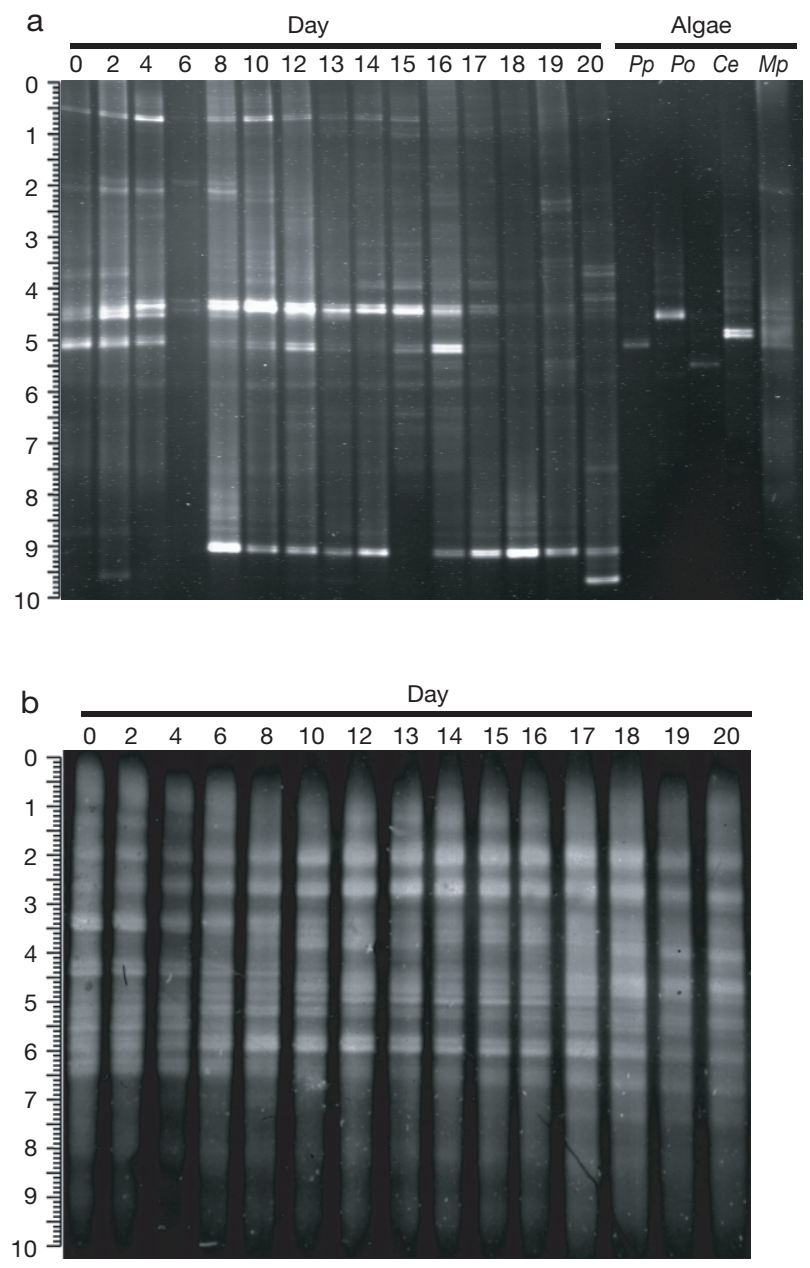

Fig. 6. PCR-DGGE profiles; band positions indicated by ruler on left. (a) Profile from analysis of eukaryotic rDNA. Standards used in last 3 lanes are PCR products from pure cultures of: Pp: Phaeocystis pouchetii; Po: Pyramimonas orientals; Ce: Chrysochromulina ericina; Mp: Micromonas pusilla. (b) Profile from analysis of prokaryotic rDNA
5.1 were identical, but they could not be identified. The band at position 9.0 appeared strong from Days 8 to 20, but was missing on Day 15. The origin of this band was probably a crustacean species, as sequence data from Days 8 and 20 show $97 \%$ and $99 \%$ similarity to Calanus pacificus. The absence of the band on one day may be due to an insufficient sampling volume compared to the actual numbers of these organisms in the sample. From Day 17 a significant shift in eukaryote community structure was observed. A DGGE profile with a higher number of bands, but none clearly dominating, was established on Days 19 and 20. The lack of bands on Day 6 is due to poor DNA recovery in the sample.

With DGGE analysis of the prokaryote DNA we found 12 to 14 distinguishable bands on each sampling day, and throughout the entire experimental period we recognised a total of 31 different band positions (Fig. 6b). The band pattern did not change dramatically at any point, although some changes could be recognized during the period. For example, a relatively strong band was found at position 3.4 initially but appeared only very faint on Day 20, and a band at position 3.8 was present on Day 20 but not during the first days of the experiment. A band at position 5.5 was present initially and at the end of the experiment, but not from Days 8 to 16 .

The general impression emerging from the prokaryote DGGE profile was that of a complex bacterial community with high, approximately similar numbers of bands each sampling day. However, the community appeared slightly different between Days 10 and 18 compared to the community in the beginning and at the end of the experiment, as certain bands (e.g. at positions $2.1,2.7,5.0,5.8)$ stood out as more dominant than others during this period. The flow cytometry results showed that during these $8 \mathrm{~d}$ a greater percentage of the total bacteria had low DNA content compared to the rest of the experimental period (Fig. 2c).

\section{DISCUSSION}

\section{General comments}

The aim of this study was to demonstrate how current techniques can be integrated to provide a more detailed picture of changes occurring in planktonic algal, bacterial and viral populations. In order to be able to follow the succession of microbial communities within the same water mass we used a nutrient enriched seawater enclosure. As we did not have parallel enclosures, or repeated experiments, our intentions were not to produce results necessarily valid for all marine systems, but rather to describe, as a case study, microbial dynamics during a phytoplankton bloom in as much detail as possible. Our results suggest that 
algal, viral and bacterial dynamics in this case were closely linked. We observed that the dominating group of algae (judged by biomass and primary production) consisted of a mixture of several flagellated species. Its maximum concentration was followed by a rapid increase of several size classes of viruses. The cooccurring bacterial community decreased in abundance during the major algal bloom and increased as the bloom declined, but the bacterial composition appeared stable throughout the experimental period.

Phytoplankton numbers and compositions reported from mesocosm experiments with similar conditions and nutrient regimes to those used here (Egge 1993, Egge \& Heimdal 1994, Jacobsen et al. 1995) are comparable our observations. Bacterioplankton rarely deviates from a range of $10^{4}$ to $10^{6}$ bacteria $\mathrm{ml}^{-1}$ in natural water samples, and free viruses range from $10^{4}$ to $10^{8} \mathrm{ml}^{-1}$ (Proctor 1997 and references therein). The abundance of bacteria and viruses in our enclosures were within these ranges. We found that viruses smaller than $87 \mathrm{kbp}$ made up a great majority of the total virus community.

\section{Succession of algae, viruses and bacteria}

The FCM-analyses demonstrated the development of 2 characteristic algal populations, A1 and A2, and 2 major virus populations, V1 and V2. A2 dominated early and A1 late in the experiment. The chl a values and primary production data indicate that $\mathrm{A} 1$ had a greater impact on the production than A2. The peak of A1 coincided with biomass and primary production while no such coincidence was observed at the time that $\mathrm{A} 2$ reached its maximum.

A2 reached maximum concentration at Day 7 before it decreased dramatically in numbers over the next $2 \mathrm{~d}$. The size and pigmentation of the algae in this population, as indicated by FCM scatter and fluorescence signals, resembled that of pure cultures of Micromonas pusilla (A.L., pers. obs.). The LM investigations, however, did not demonstrate a corresponding population. M. pusilla is claimed not to be countable with routine phytoplankton procedures due to its small size and difficulty of preservation (Zingone et al. 1999), indicating that the A2 algal population could indeed be this very species. The band at level 0.7 on the eukaryote DGGE profile was quite dominant in the beginning of the experiment but disappeared at Day 12 and therefore indicates that the algae of the A2-population could have given rise to this band. The band did not correspond with the band position of cultured M. pusilla, however. In conclusion, it seems justifiable to claim that A2 was not M. pusilla, but consisted of 1 (or more) species resembling it in both size and pigmentation.
The density of this Micromonas-like population decreased relatively rapidly without any indications of nutrient scarcity in the mesocosm. We therefore assume that the decrease was caused by grazers or by viral lysis. Among potential grazers, several ciliate species were observed in the mesocoms most of the period. The maximum concentration of ciliates (ca 100 cells ml- ${ }^{-1}$, data not shown) did not occur until Day 17 however, i.e. too long after the observed decrease in the Micromonas-like population to be the probable cause of the decrease. The DGGE profile, in combination with sequence data that were most similar to a Calanus pacificus sequence (not shown), indicates the presence of a crustacean species in the mesocosm as well. However, crustaceans as big as Calanus sp. are not likely to feed heavily on small organisms like Micromonas-sized ones (Jonsson 1986, Riegman et al. 1993, Hansen et al. 1994, Nejstgaard et al. 1995). We therefore believe the sudden decrease in this algal population could have been brought about, at least in part, by viral lysis. The V2 population, as determined by the FCM-analysis, reached maximum concentration around Day 7. Moreover, the PFGE-analyses demonstrated that viruses with size 224 and 230 also reached maximum abundance at Day $7 . \mathrm{MpV}$-viruses can be found in this size range (Brussaard et al. 2000), and these size classes of viruses could thus be the cause of the rapid decrease in the Micromonas-like algal population.

The A1 algal population increased to a maximum at Day 14 before it quickly decreased again. The flow cytometric data indicate that the group was composed of more than 1 species. The LM investigation showing that 3 algal groups reached maximum values from Days 13 to 15 , namely 6 to $10 \mu \mathrm{m}$ sized unidentified flagellates, 2 to $5 \mu \mathrm{m}$ sized unidentified flagellates and prasinophytes (mainly Pyramimonas spp.), confirms this indication. The eukaryote DGGE profile also supports the impression of a mixed population. The profile even suggests the origin of the bands at level 4.4 and 5.1, as they correspond to the position of Pyramimonas orientalis and Phaeocystis pouchetii respectively. The 4.4 level band cut out for sequencing on Days 13 and 20 had identical sequences when ignoring ambiguous bases. However, neither the identity of the origin of this nor of the 5.1-level band could be determined by the sequencing data. Still, by combining the information from the DGGE profile with the knowledge obtained from LM and FCM, it is reasonable to suggest that 1 dominating species of A1 could have been $P$. orientalis or a species closely related (and thus with a similar migration pattern). This assumption was strengthened by the TEM observations, which demonstrated that Pyramimonas cirolanae in addition to another Pyramimonas species were present in the enclosure. 
Flagellated $P$. pouchetii cells could also have contributed to the A1 population as colonies of this species were observed in low abundance in the enclosure. These cells are difficult to preserve; they have a short haptonema and few characteristics visible in LM. In fixed material flagellated $P$. pouchetii cells are therefore almost impossible to distinguish from other small haptophycean species such as Imantonia rotundata and Dicrateria inornata, and may thus have contributed to the 2 to $5 \mu \mathrm{m}$ sized unidentified flagellates. The DGGE profile demonstrated a significant shift in the eukaryote community from Day 17. More bands, but none clearly dominating, appeared after the dominating bands corresponding to that of $P$. orientalis and $P$. pouchetii disappeared, thus making it highly probable that a variety of species made up the unidentified flagellates of both size groups. The TEM observations indicate that at least some of these were species of Chrysochromulina.

A1 decreased rapidly without any clear long-lasting nutrient deficiency in the bag. Ciliates, which reached their maximum concentration at Day 17, probably account in part for the observed decrease. However, the increase of V1 indicates that viral lysis might have been an additional reason. The appearance of metazoans, as inferred from the eukaryote DGGE bands at level 9.0 and 9.6, strengthen this assumption as viral lysis of primary producers might increase the carbon flow to higher trophic levels (van Hannen et al. 1999). The band at 9.0 was cut out for sequencing at Day 8 and Day 20, and the sequence data showed 97 and $99 \%$ similarity to Calanus pacificus respectively. The 9.0 level band first appeared at Day 8, which was soon after the sudden decrease in A2, and increased in strength after the sudden decrease in A1 (Day 17). Its absence on $1 \mathrm{~d}$ may be due to the small sampling volume compared to the size and density of these organisms.

The 4 peaks that emerged from the PFGE analyses at Day 13 support the idea of viral attack as conducive to the sharp reduction of the algal concentration. The 4 peaks also suggest that V1 is composed of several virus types. There are reasons to believe that a single algal species can be infected by more than 1 viral type or size class (Ivey et al. 1996, Nagasaki \& Yamaguchi 1998, Sahlsten 1998, Zingone et al. 1999). The possibility that the 4 PFGE-bands peaking at Day 13 represent viruses that are able to infect only 1 algal species can therefore not be discounted. However, as we argued earlier, A2 is likely to consist of a variety of algal species, nor can we exclude the possibility that the viruses are specific to different species and may have contributed to mortality in more than 1 algal population. Compared to the FCM signatures from the virus observed in culture, V1 could resemble an Emiliania huxleyi virus (EhV), a Phaeocystis pouchetii virus $(\mathrm{PpV})$, a Pyramimonas orientalis virus $(\mathrm{PoV})$ or a Chrysochromulina ericina virus (CeV). As E. huxleyi was not observed in the enclosure it is unlikely that EhV made up a significant part of V1. When measured in our cultures, the 3 other viruses mentioned have genome sizes from 430 to $>500 \mathrm{kbp}$ while those reaching maximum concentration at Day 13 were in the range from 87 to $194 \mathrm{kbp}$. Therefore, if $P$. orentalis was the major contributor to A1 and the main reason for its decline was viral lysis, there has to be a smaller virus in addition to the one we have isolated that caused mortality in $P$. orientalis. The viruses with sizes $437 \mathrm{kbp}$ and $485 \mathrm{kbp}$ might well be $\mathrm{CeV}$ and or $\mathrm{PpV}$. Their presence might indicate that $P$. pouchetii and/or C. ericina were contributors to A1 and that their decrease might also have been caused by viral attack. However, taking into account that we have only a few virus-host systems available in culture and that other viruses may well have similar properties, this must be considered speculation.

The 2 additional algal groups (A3 and A4) detected by FCM almost disappeared after ca $8 \mathrm{~d}$ and were found in relatively small numbers. It is therefore difficult to determine with certainty which of the groups determined by LM corresponds to these. The high RFL, OFL and SSC values of A4 do indicate, however, that the population consisted of cryptophytes. This assumption is strengthened by the LM data, which show that cryptophycean species were found in highest numbers during the beginning of the experiment. The population might correspond to the eukaryote DGGE band appearing at level 2.1. The band was present at Days 2 and 4 and then disappeared. We believe that the A3 population consisted of Synechococcus sp., as the high OFL signals and low SSC and RFL signals are properties consistent with that of Synechococcus. Because of its small size, Synechococcus is not countable with routine phytoplankton procedures and thus the LM data cannot be used for verification of this assumption. Nor could the prokaryotic DGGE profile be used for this purpose, as we do not know the band position emerging from DNA of cultured Synechococcus.

The FCM data indicate that the bacterial community was made up of several species. A high bacterial species richness, with a relatively stable composition, is the impression given by the prokaryote DGGE profile as well. The initial and terminal DGGE profiles were quite similar, although some bands initially present disappeared, and some that had not been present appeared towards the end.

Among the potential host organisms, bacterioplankton was found in higher concentrations than phytoplankton. It is therefore tempting to interpret the viruses with the highest abundance, i.e. those smaller 
than ca $87 \mathrm{kbp}$ (see Fig. 5a), as bacteriophages. However, we did not observe any dramatic changes in the bacterial community composition indicating viral removal of entire bacterial populations, although the total bacterial numbers did vary in the course of the experimental period. We therefore speculate that this might indicate that the bacteriophages contributed in keeping a variety of bacterioplankton species at nonblooming but oscillating levels.

\section{Concluding remarks}

This is the first time that succession and interaction among algae, viruses and bacteria have been investigated at such a level of resolution. We were not able to identify all species in our samples due to limitation of the methods we used. Traditional light microscopy has limitations for identification, especially in samples dominated by naked flagellates, which due to their small size and difficulty of preservation are to a large extent not countable with routine phytoplankton procedures. In order to obtain reliable species identifications by sequencing, one needs longer fragments than those that we used for sequencing DNA from the PCRDGGE bands. One also has to take into consideration that the DNA in the bands cut out of the DGGE gels have been exposed to UV light during the laboratory work and thus may be damaged, and that the bands on such gels may contain contamination of other sequences. Moreover single stranded DNA and circular DNA will not be detected by PFGE, while fragmented viruses will be. Species-specific probes used in combination with FCM and/or PFGE would most certainly improve results from an investigation like this. Similarly, with a flow cytometer equipped for cell sorting it would have been possible to isolate unknown populations for identification by microscopy or molecular methods. However, our results clearly illustrate that the combination of methods we used enabled us to detect species that would have been overlooked earlier. The best example is perhaps the detection of the Micromonas-like and Synechococcus populations, which would not have been possible without FCM/ PCR-DGGE. The combination of the various methods also enabled us to demonstrate that several of the different viruses detected increased as the algal and bacterial populations reached their maxima, and that the algal/bacterial population subsequently decreased in density. Our results thus suggest a close linkage between algal, bacterial and viral populations. The virioplankton do not necessarily terminate the blooms but may keep the algal and bacterial populations at nonblooming levels. The current investigation adds to an increasing amount of studies showing that viruses may control the densities that can be maintained within algal and bacterial populations (Cotrell \& Suttle 1991, Suttle \& Chan 1995, Zingone et al. 1999) and underlines the potential importance of viruses as regulating factors within the microbial community structure.

Acknowledgements. This work was supported by grants from The Research Council of Norway (projects 113037/120 and 121425/420) and the EU MAST-III program (project MIDAS, contract MAS3-CT97-0154). The FACSCalibur flow cytometer was in part funded by a grant from The Knut and Alice Wallenberg Foundation to the Virtue program. Transmission electron microscopy was carried out at the Laboratory for Electron Microscopy (LEM), UiB, and thanks are due to Egil $\mathrm{S}$. Erichsen and Harald Landa for their assistance in this work. We also thank Jahn Throndsen and Wenche Eikrem for help with the scale identification, and Øivind Enger for the bacterial DNA isolation protocol.

\section{LITERATURE CITED}

Bergh Ø, Børsheim KY, Bratbak G, Heldal M (1989) High abundance of viruses found in aquatic environments. Nature 340:467-468

Bratbak G, Heldal M (1993) Total count of viruses in aquatic environments. In: Kemp PF, Sherr BF, Sherr EB, Cole JJ (eds) Current methods in aquatic microbial ecology. Lewis Publishers, Boca Raton, p 135-138

Bratbak G, Egge JK, Heldal M (1993) Viral mortality of the marine alga Emiliania huxleyi (Haptophyceae) and termination of algal blooms. Mar Ecol Prog Ser 93:39-48

Brussaard CPD, Marie D, Bratbak G (2000) Flow cytometric detection of viruses. J Vir Methods 85:175-182

Collier JL (2000) Flow cytometry and the single cell in phycology. J Phycol 36:628-644

Cotrell MT, Suttle CA (1991) Wide-spread occurrence and clonal variation in viruses which cause lysis of a cosmopolitan, eukaryotic marine phytoplankter, Micromonas pusilla. Mar Ecol Prog Ser 78:1-9

Egge JK (1993) Nutrient control of phytoplankton growth: effects of macronutrient composition (N, P, Si) on species succession. Dr Scient thesis, University of Bergen

Egge JK, Aksnes DL (1992) Silicate as regulating nutrient in phytoplankton competition. Mar Ecol Prog Ser 83: 281-289

Egge JK, Heimdal BR (1994) Blooms of phytoplankton including Emiliania huxleyi (Haptophyta). Effects of nutrient supply in different N:P ratios. Sarsia 79:333-348

Egge JK, Jacobsen A (1997) Influence of silicate on particulate carbon production in phytoplankton. Mar Ecol Prog Ser 147:219-230

Gargas E (1975) A manual for phytoplankton primary production studies in the Baltic. The Baltic Marine Biologists, Publication No. 2. The Danish Agency of Environmental Protection, Hørsholm

Hagebø M, Rey F (1984) Lagring av sjøvann til analyse av næringssalter. Fisken Havet 4:1-12 (in Norwegian with English summary)

Hansen B, Bjørnsen PH, Hansen PJ (1994) The size ratio between planktonic predators and their prey. Limnol Oceanogr 39:395-403

Ivey RG, Henry EC, Lee AM, Klepper L, Krueger SK, Meints RH (1996) A Feldmannia algal virus has 2 genome sizeclasses. Virology 220:267-273 
Jacobsen A, Egge JK, Heimdal BR (1995) Effects of increased concentration of nitrate and phosphate during a springbloom experiment in mesocosm. J Exp Mar Biol Ecol 187: $239-251$

Jacobsen A, Bratbak G, Heldal M (1996) Isolation and characterization of a virus infecting Phaeocystis pouchetii (Prymnesiophyceae). J Phycol 32:923-927

Jonsson P (1986) Particle size selection, feeding rates and growth dynamics of marine planktonic oligitrichous ciliates (Ciliophora: Oligotrichina). Mar Ecol Prog Ser 3: 265-277

Marie D, Brussaard CPD, Thyrhaug R, Bratbak G, Vaulot D (1999a) Enumeration of marine viruses in culture and natural samples by flow cytometry. Appl Environ Microbiol 65:45-52

Marie D, Brussaard CPD, Partensky F, Vaulot D (1999b) Enumeration of phytoplankton, bacteria and viruses in marine samples. In: Robinson JP, Darzynkiewicz Z, Dean PN, Orfao A and 4 others (eds) Current Protocols in Cytometry. John Wiley \& Sons, Chichester, p 11.11.1-11.11.15

Maule J (1998) Pulsed-field gel electrophoresis (review). Mol Biotechnol 9:107-126

Muyzer G (1999) DGGE/TGGE: a method for identifying genes from natural ecosystems. Curr Opin Microbiol 2: $317-322$

Muyzer G, de Waal EC, Uitterlinden AG (1993) Profiling of complex microbial populations by detaturing gradient gel electrophoresis analysis of polymerase chain reactionamplified genes encoding for 16SrDNA. Appl Environ Microbiol 59:695-700

Nagasaki K, Yamaguchi M (1998) Intra-species host specificity of $\mathrm{HaV}$ (Heterosigma akashiwo virus) clones. Aquat Microb Ecol 14:109-112

Nagasaki K, Imai I, Itakura S, Ando M, Ishida Y (1995) Viral infection in Heterosigma akashiwo (Raphidophyceae): a possible termination mechanism of the noxious red tide. In: Lassus P, Arzul G, Erard E, Gentien P, Marcaillou C (eds) Harmful marine algal blooms. Intercept Ltd, Andover, p 639-644

Nejstgaard JC, Båmstedt U, Bagøien E, Solberg PT (1995) Algal constraints on copepod grazing. Growth state, toxicity, cell size, and season as regulating factors. ICES J Mar Sci 52:347-357

Øvreås L, Forney L, Daae FL, Torsvik V (1997) Distribution of bacterioplankton in meromictic Lake Sælenvannet, as determined by denaturing gradient gel electrophoresis of PCR-amplified gene fragments coding for 16S rRNA. Appl Environ Microbiol 63:3367-3373

Parsons TR, Maita Y, Lalli CM (1984) A manual of chemical

Editorial responsibility: Otto Kinne (Editor),

Oldendorf/Luhe, Germany and biological methods for seawater analysis. Pergamon Press, Oxford

Proctor LM (1997) Advances in the study of marine viruses. Microsc Res Tech 37:136-161

Riegman R, Kuipers BR, Noordenloos AAM, Witte H J (1993) Size-differential control of phytoplankton and the structure of plankton communities. Neth J Sea Res 31:255-265

Sahlsten E (1998) Seasonal abundance in Skagerrak-Kattegat coastal waters and host specificity of viruses infecting the marine photosynthetic flagellate Micromonas pusilla. Aquat Microb Ecol 16:103-108

Schauer M, Massana R, Pedros-Alio C (2000) Spatial differences in bacterioplankton composition along the Catalan coast NW Mediterranean assessed by molecular fingerprinting. FEMS Microbiol Ecol 33:51-59

Steeman Nielsen E (1952) The use of radioactive $\left({ }^{14} \mathrm{C}\right)$ for measuring organic production in the sea. J Cons Perm Int Expl Mer 18:117-140

Suttle CA, Chan AM (1995) Viruses infecting the marine Prymnesiophyte Chrysochromulina spp.: isolation, preliminary characterization and natural abundance. Mar Ecol Prog Ser 118:275-282

Troussellier M, Courties C, Vaquer A (1993) Recent applications of flow cytometry in aquatic microbial ecology. Biol Cell 78:111-121

Utermöhl H (1931) Neue Wege in der quantitativen Erfassung des Planktons. (Mit besonderer Berücksichtigung des Ultraplanktons). Verh Int Ver Theor Angew Limnol 5:567-596

van Hannen EJ, van Agterveld MP, Gons HJ, Landbroek HJ (1998) Revealing genetic diversity of eukaryotic organisms in aquatic environments by detanuring gel electrophoresis. J Phycol 34:206-213

van Hannen EJ, Zwart G, van Agterveld MP, Gons HJ, Ebert J, Landbroek HJ (1999) Changes in bacterial and eukaryotic community structure after mass lysis of filamentous cyanobacteria asociated with viruses. Appl Environ Microbiol 65:795-801

Vives-Rego J, Lebaron P, Nebe-von Caron G (2000) Current and future applications of flow cytometry in aquatic microbiology. FEMS Microbiol Rev 24:429-448

Wommack KE, Colwell R (2000) Virioplankton: viruses in aquatic ecosystems. Microbiol Mol Biol Rev 64:69-114

Wommack KE, Ravel J, Hill RT, Chun J, Colwell R (1999) Population dynamics of Cheapeake Bay virioplankton: totalcommunity analysis by pulsed-field gel electrophoresis. Appl Environ Microbiol 65:231-240

Zingone A, Sarno D, Forlani G (1999) Seasonal dynamics in the abundance of Micromonas pusilla (Prasinophyceae) and its viruses in the Gulf of Naples (Mediterranean Sea). J Plankton Res 21:2143-2159

Submitted: December 29, 2000; Accepted: June 28, 2001

Proofs received from author(s): September 21, 2001 